\title{
AN ANALYSIS OF POLITENESS STRATEGIES USED BY FEMALE AND MALE STUDENTS IN XI IIS OF SMA BHAKTIYASA SINGARAJA TO TALK TO THEIR TEACHERS INSIDE AND OUTSIDE THE CLASSROOM
}

\author{
N. W. Sugitariani, I. K. Seken, I. N. P. Hadisaputra \\ Jurusan Pendidikan Bahasa Inggris \\ Universitas Pendidikan Ganesha \\ Singaraja, Indonesia \\ Email: sugitariani.id@gmail.com, iketutseken@gmail.com, \\ pasek hadisaputra@yahoo.com
}

\begin{abstract}
Abstrak
Penelitian ini bertujuan untuk menjelaskan jenis-jenis strategi kesantunan yang digunakan siswa perempuan dan laki-laki di kelas XI IIS SMA Bhaktiyasa Singaraja untuk berbicara dengan para guru mereka saat di dalam kelas dan diluar kelas dan alasan mereka menggunakan strategi kesantunan tersebut. Subjek penelitian ini ialah para siswa di kelas XI IIS SMA Bhaktiyasa Singaraja yang berbicara dengan guru-guru mereka.Peneliti merupakan instrument utama pada penelitian ini yang mengumpulkan data dengan merekam suara percakapan siswa dengan guru, mencatat fenomena yang terjadi, dan mewawancarai subjek penelitian.Strategi kesantunan yang digunakan oleh siswa dianalisis berdasarkan teori kesantunan Brown \& Levinson. Hasil penelitian menunjukkan bahwa strategi yang digunakan ialah bald on record politenesspositive politeness, dan off record.Bald on record impolite language merupakan strategi yang paling sering digunakan oleh siswa baik di dalam kelas maupun diluar kelas.Sebagian besar, siswa mengunakan bahasa tidak santun yang dapat disebut sebagai kesalahan pragmatik karena siswa memiliki motif untuk menadi lebih dekat dengan guru-guru mereka.Hal ini berbeda dengan penelitian-penelitian sebelumnya yang menunjukkan bahwa positive politeness strategy yang banyak dipilih saat berbicara dalam situasi formal.Penelitian ini menunjukkan siswa menggunakan impolite language bahkan pada saat mereka berbicara dengan guru di dalam kelas. Hasil tersebut mengindikasikan bahwa siswa jarang menggunakan strategi kesantunan dalam berbicara dengan guru, bahkan dalam situasi formal.Alasan para siswa menggunakan bahasa tidak santun karena mereka merasa mereka dekat dengan para guru.
\end{abstract}

Kata kunci : Kesalahan Pragmatik, Strategi Kesantunan, Strategi Komunikasi

\begin{abstract}
This study aimed to explain the types of politeness strategies used by female and male students of XI IIS of SMA Bhaktiyasa Singaraja to talk to their teachers inside and outside the classroom and the reason of using those strategies. The researcher was the key instrument in this study that collected the data by audio-recording the conversation between students and teachers, taking note of the phenomena and interviewing the subject of the study. The subjects of the study were the students in XI IIS of SMA Bhaktiyasa Singaraja who talked to their teachers. The politeness strategies used by students were analyzed based on Brown \& Levinson's theory of politeness. The result of this study showed that the strategies used by female and male students were bald on record politeness, positive politeness, and off record. Mostly, the students used impolite language which can be stated as pragmatic errors because the students' motive was to get closer to the teachers so they used impolite language. It was different from the
\end{abstract}


previous studies that indicated positive politeness strategy most used by speaker in formal situation. The result of this study indicated that the students used politeness strategies rarely even when they talked to their teachers in the classroom activities. The students' reasons of using the impolite language most frequently than politeness strategies because they felt they were close with the teachers so that they used impolite language to show their friendliness.

Key words $\quad$ : Communication Strategies, Politeness Strategies, Pragmatic Error 


\section{INTRODUCTION}

Politeness is an important aspect in communication. A speaker should consider whether the language that he/she chooses is appropriate for sharing with the interlocutor or not and that is why politeness should be used in communication. Politeness is the expression of the speakers' intention to mitigate face threats carried by certain face threatening acts toward another (Mills, 2003, as cited in Bayles, 2009). It means that politeness is an expression to treat someone by expressing our intention which is carried by certain face threatening acts.

According to Petrickova (2012) gender influence the language used to talk to someone. A male interviewer chooses different politeness strategy to the male and female interviewee. The interviewer tends to use positive politeness as the strategy to talk to a male interviewee (Petrickova, 2012 p.36). But when a female interviewer interviewed someone, she chose negative politeness. Questions of negative interrogative have the function of expressing point of view, rather than demand for information (Petrickova, 2012 p.36).

Impolite language is the use of strategies which were designed to cause social disruption instead of maintaining social harmony (Culpeper in Laitinen, 2010). Impolite language can create negative emotional consequences for at least the hearer (Culpeper, 2011). Impolite language is an act that can make the hearer feel disrupted and attack the hearer's emotional negatively.

Melina Laitinen (2010) found that impolite language strategies were used because the speaker has no any interest for being likeable to someone else. She found that a doctor in the American TV series were a very direct person who used impolite language when he talked to his patients. One example of his utterance is, "And you are very bad at whatever it is you do". He used impolite language which defines as a direct language. Bald on record impolite language is not very different from bald on record politeness.
This impolite language strategy is just used even though the situation where the threat to the hearer's face is possible and there is no great urgency.

This year, SMA Bhaktiyasa only has one class for the XI grade. It is XI IIS Class. All of the students in XI IIS class are from Buleleng Regency. The language used by them is the language that generally used by people in Buleleng. Buleleng people have unique ways in talking one to another. They use language that in some regencies in Bali are generally known as impolite language. However, in Buleleng the language is still categorize as polite. From the prior obeservation the researcher found that the students of XI IIS class often talk to some teachers not only in the classroom but also outside the classroom.

SMA Bhaktiyasa Singaraja is one of senior high school in Singaraja. This school has few students. Most of the students are the students who are transferred from another school. The reason of moving to SMA Bhaktiyasa is vary. Some of them moved to SMA Bhaktiyasa because they had problem at previous school both academically and non-academically, while the other students moved because they had problem in economic side. SMA Bhaktiyasa Singaraja offers the students a scholarship for the students who have economic problem.

The students' behavior in SMA Bhaktiyasa Singaraja is different from the students that generally study in other schools. From the prior-observation the researcher saw that the communication occurred between students to teacher are sometimes out of the rules of politeness. Students usually talk to their teacher as they talk to their friends. There is no any relationship gap between students and some teachers in the school including the communication occurred in the classroom and outside the classroom. This is the reason why the researcher interested in studying the phenomena in SMA Bhaktiyasa Singaraja.

Generally, in SMA Bhaktiyasa Singaraja, the use of politeness of the students in communicating to the teacher is still in confusement, whether it is used 
appropriately or not. From the prior observation, the researcher found a phenomenon. Some male students chose to say, "Buk! Bin pidan teke pise (beasiswa)?" (Miss! When will my scholarship be given to me?) to the female teacher. When some of female students tend to talk to female teacher like this; "ah ibu ini bisa ajha. Yen tiang sing be nyemak gae keto buk." (ah don't say like that. If I were you, I would not do it). The researcher was interested in studying male and female students' politeness and impolite language strategies used to talk to their teachers in SMA Bhaktiyasa Singaraja deeply by conducting the observation in SMA Bhaktiyasa Singaraja.

\section{METHOD}

This study was a qualitative study which was focused on investigating the phenomena of politeness and impolite language strategy used by female and male students in XI IIS of SMA Bhaktiyasa Singaraja to talk to their teachers inside and outside the classroom. The subject of this study was selected through purposive sampling. XI IIS class was selected because all the students were from Buleleng Regency who used Buleleng dialect.

The main instrument of this study was the researcher. The researcher was the one who understood what should be done during the research. For helping the researcher to get data, the researcher used some devices, such as: (1) Audio Recorder; (2) Field Note; and (3) Interview Guide. Those devices were used to get valid data from the subject of this study.

The data were collected through audio recording and taking note of the phenomena. The researcher recorded the whole activities in the classroom to get data of students' conversation in the classroom. to get data of the students' conversation outside the classroom, the researcher recorded the conversation while the students talking to their teachers in cafeteria or near to their classroom. After recording and taking a note, the researcher transcribed the recording. The transcription was analyzed to classify the politeness strategies that XI IIS students used when they talked to their teachers. After the researcher classifying the data, the researcher confirmed the reason of using the strategies to the students through interview. Those data of conversation and interview were analyzed. The data were displayed in a form of description.

To prove that the data was reliable and valid, the researcher used triangulation. The researcher used methodological and data triangulation. Methodological triangulation means that the researcher used more than one procedure to collect data. Data triangulation means that the researcher used more than one sources to avoid the weaknesses of the data.

\section{FINDINGS AND DISCUSSIONS}

Politeness and impolite language strategies which were used by XI IIS students to talk to their teachers were classified into; (1) politeness and impolite language strategies which were used by XI IIS students to talked to their teachers in the classroom, and (2) politeness and impolite language strategies which were used by XI IIS students to talk to their teachers outside the classroom.

Strategy which was used by the students to talk to their teacher in the classroom was impolite language and bald on record politeness strategy. Both female and male students used impolite language to talk to their teachers. Some examples of students' expressions using impolite language can be seen as follows:

(1) M3: (after being in front, he was confused) Nak kenken ibuk e? nulis di papan kan buk o?

What is wrong with you? I should write the sentence on the board, shouldn't I?

(2) M4: Istirahat buk! (the bell rang and the students had been impatient to enjoy the break time)

It has been break time, buk!

(3a) T1: Itu "study" tulisannya kan bukan "stady". 'u' dipakai ya! 
Write "study" not "stady". You must write it with "u"!

(3b) M5: Yang mana?

Which one?

(4) M4: Berpikir nu buk!

[l am] still thinking buk

The expressions above were told by male students in XI IIS class when they learned English. The expressions above were expressed by using impolite language.

(11) M2: Pak bawa pulpen pak? Pak, do you bring any pen?

(12) M3: Engkenang mulai ne? How to start this?

The expressions above were uttered by two male students in Bahasa Indonesia class. They used impolite language.

Female students expressed an utterance using impolite language in the classroom activities and the second utterance was used bald on record politeness. The utterances which were expressed by female students in XI IIS can be seen as follows:

(8) F1 : Konden ulung nasine kone buk!

The rice has not been swollen yet, he said Buk

(13) F1: Semuanya pak ya?

All of these, pak?

Both male and female students used impolite language to talk to their teachers in the classroom. Brown \& Levinson theory explained that bald on record strategy is a strategy that does not attempt the speaker to minimize the face threat. However, the formal situation caused the expression was indicated using impolite language strategy than using politeness strategies. Impolite language is a language which is negatively evaluated in a particular context (Culpeper, 2011). Culpeper (2011) Impolite language could attack someone's identity or rights which might cause him/her anger or hurt. This happened frequently in XI IIS class. The students uttered their expressions directly without any redress when they answering the teachers' questions and asking questions to the teacher. The students did not add any redress on their utterance during classroom activities because in the classroom activities they answered the question directly after the teacher asked question without thinking of the best language they should used.

According to the previous study conducted by Pinatih, in a formal situation positive politeness was frequently appeared. Peng et al. (2014) also found that in the classroom activities, the speaker used positive politeness and negative politeness. Positive politeness was used in giving compliment or addressing the interlocutor while negative politeness was used in asking something to the interlocutor. In this case, the speaker was a college teacher who taught EFL students. However, on this research the researcher found that in the formal situation; in classroom activities, the speakers; the students of XI IIS class chose to use impolite language. Based on the interview conducted with some students in XI IIS, it was found that the reason of using this strategy because they thought that they were close enough to the teachers to talk baldly even if it was in the classroom.

On this study, the researcher found that both female and male used same strategy to talk to their teachers in the classroom. It was different from the previous study about politeness strategy used by male and female interviewer when they interviewed some people (Petrickova, 2012). On her study, the male interviewer used positive politeness and the female interviewer tends to use negative politeness. However, on this study the researcher found that there was no any difference strategy that female students and male students chose. Both female and male students used bald on record strategy.

From the interview conducted by the researcher, the students stated that 
the reason why they talked directly and baldly to the teacher in the classroom activities because they used to do it. Some mal students stated that they used to asked question baldly or stated something baldly to the teacher since they were close to the teachers. Some female students stated that they were talked baldly in the classroom because they did not do it purposively. They did it if they were suddenly asked to do something or if they were surprised because of something.

Pinatih (2014) found that in formal situation (Pasraman), people tend using positive politeness. Talking in the classroom is also categorized as formal situation. However, the students in XI IIS of SMA Bhaktiyasa Singaraja did it differently. They used bald on record when they talked to their teachers in the classroom. The reasons of using the strategy commonly because of they used to do it in the classroom as the students stated. The habit of expressing something baldly in the classroom when talking to the teachers happened in XI IIS class. From the observation the researcher found that the teachers did not mind the students' expressions. The teachers' response strengthened the students' statement that they used to talk in that way to the teacher.

Students in XI IIS were also talking to their teachers outside the classroom. The utterances they used were bald on record, positive politeness, and negative politeness. Bald on record strategy was the most used strategy on this study. The students; both male and female students used bald on record strategy when they talked to the teacher in some occasions outside the classroom. These are the utterances which were said by the students when they talked to their teachers outside the classroom:

(16) M2: Yen sing maan pelajaran dadi pak

If there is no any lesson, we are allowed to go home

(21a) T5: lje kelas $X$ ?

Where are the $X$ grade students? (21b) M6: Ngukur baju.. uniform

Measuring the size of their

(24a) T5: Kelas IPA nya dimana?

Where is the science class?

(24b) M3: Mati..(He said sarcastically and left the others to enter the classroom.)

Died..

(30a) T5: Kedasin ne! (point on the window).., Uli sisi atenge..

Clean this! Half of you clean from the outside the classroom..

yeh..

(30b) M1: Nden malu pak ..nyemak

(31) M1: Eh pak ne kelas XII IPS e nyabat nyabat pak..

Eh pak, the XII grade students hit me by this wet newspaper...

All of the utterances above were the expressions that used impolite language. All the expressions above were said by male students.

These were the utterances said by female students which used bald on record strategy:

(18) F1: Ne gurune main game gen gaene..wifi gen..

This teacher just spent his time to play game using $\mathrm{Wi}-\mathrm{Fi}$..

(19) F1: Bapak e be gara-gara nganggo gelem dadine..

It is because of you who use it till it broken

(20) F3: Oooh pak..ne be kejemakang jak yang... iiih... iiih...

See.., I have taken your meal,,,

(23) F1 : Pak..., Ngeplakin be... Pak..you hit me..

(25a) T5: Apa pelajarannya sekarang? now?
What is the lesson you have 
pak.

(25b) F1: Sekarang..? Ekonomi

Now..?Economy pak?

(26a) T5: Siapa ngajar?

Who teaches you?

(26b) F1: Bu Kartika pak

(29) F3: Ape .. Jangin nake yeh...ape kaden.. (F3 look at T5) yang nak be nyampat pak..

What [did you say?] take some water are you playing the water or something.. I have swept the floor well ne?

(32a) T6: Ne be suud? Adi negak sit here?

(32b) F,students: be.. be suud pak Yes..we have done...

(33a) T6: ment kenene be? How about the..

(33b) F2: apane? What?

The expression below was categorized as bald on record politeness because the speaker minimize FTA implicitly.

(22) F1 : Ngukur baju dia pak... They are measuring their uniform, pak.

Besides, female student used positive politeness when she talked to a new teacher. But after she met the new teacher for several times, she changed the strategy into bald on record.

(14) F1: Bapak dari panji? Nenek saya disana

Are you from Panji? My grandma lives there

She also used positive politeness when she wanted to congratulate her Balinese teacher for the teacher's birth day.

(34) F1: Mek.. Mek..dibi memek ulang tahun mek o? ibi ukanange pang dadi ane pertama, memek sing ade..
Mek.., Mek..Yesterday was your birth day, wasn't it? Yesterday I really wanted to say 'happy birth day' but memek did not come..

Off record strategy was also used by a male student and a female student from XI IIS class.

(17a) T4: Nyen gen di kantor? Who are in the office?

(17b) F1: Nyen asane nah? I am not sure..

Impolite language was also appeared when the students talked to the teachers outside the classroom. This strategy often appeared when the students talked to the teachers about some topics. When a student of XI IIS class answered a teacher's question about students that he would teach by saying,

$$
\text { M3 :Mati! }
$$

(they were dead!)

It showed that the student used bald on record impolite language expression. From the interview he confirmed that he uttered that word because he thought it was just a joke.

The students used impolite language because they felt that the direct utterances would refer to a close relationship. It was explained by Brown \& Levinson (1987) on their theory that bald on record strategy could be happened if the speaker has close relationship with the interlocutor. The students wanted to be close with the teachers so they used this strategy to talk as close as possible to the teachers.

The female students did not use bald on record impolite language only when they talked to their teachers. They used positive politeness strategy when they talked to a new teacher and the teacher whose birth day was reminded by the student the day after her birth day. They used positive politeness strategy to show their respect to the teacher. In this case, the students recognized the interlocutors' desire to be respected so they used the expression that showed their impression to the interlocutors.

When a female student did a conversation with a new teacher about the address of the teacher, the student asked, F1 :Bapak dari Panji? (Are you from Panji?) 
The student showed her respect by showing that she interested in the topic of the conversation. The student's feeling expressed that she realized about the desire to be respected that the new teacher had when he talked about where he was from. The reason she used positive politeness strategy when she talked to the new teacher, because it was the first time she met the teacher. She stated that she still did not know the teacher well and because the teacher came from the same village as her mother she interested in talking to him. According to Pariera (2006, p.18), the speaker tend to use impolite language with close friends than strangers. It was proved by the strategy found on this study that the speaker who usually talked to her teachers using bald on record impolite language, used positive politeness to a new teacher.

Other case happened when a female student congratulate the teacher on the next day after her birth day. She said,

$$
\begin{aligned}
& \text { F1 :mek.., mek dibi kan ulang } \\
& \text { tahun memek e o? mare } \\
& \text { ukanange dadi ane } \\
& \text { pertama, jek sing ade. } \\
& \text { (mek.., mas your birth } \\
& \text { yesterday was } \\
& \text { day wasn't it? I hoped I will } \\
& \text { be the first [who } \\
& \text { congratulate you] but you } \\
& \text { did not come)". }
\end{aligned}
$$

The expression, "mek..,mek.." was the expression that indicated the student use in-group identity marker. Based on the theory proposed by Brown \& Levinson (1987), there is a strategy in expressing something used positive politeness. The strategy is strategy number 4 which used in-group identity. A female teacher is usually called as "ibu" or "Bu guru". In this case, it was different. The student use "mek" to call their Balinese teacher. The "mek" utterance was categorized as ingroup identity that only used by the students in SMA Bhaktiyasa to call the Balinese teacher. The following utterance showed that she respected the teacher. She said that she wanted to be the first student who congratulated the teacher.
This utterance showed respectful feeling that the female student had for the teacher. The respect and the group identity indicated the female student used positive politeness when she talked to the Balinese teacher.

(27) M6: Pak idih jenggote pak..melah gati (laughing)

Pak.., can I have your beard.., it is so good

He told a joke so that was why he was categorized to use positive politeness.

The other strategy which appeared was off record strategy. Off record strategy was used by the students to talk to the teacher that the meaning of the utterances was told implicitly. There are two expressions which was using off record strategy. The first expression was told by a female student and the other expression was told by a male student.

The first utterance was told by a female student when she was asked by the teacher whether there are teachers in the office or not. The female student answered the question by saying,

$\mathrm{F} 1$ :Nyen asane nah..?

(I am not sure about it)

The expression showed that the student told the teacher implicitly that she did not know the answer. The reason she answered the teacher's question in that way was because she did not really know who were in the office and asked her friend implicitly to help her telling the teacher who were in the teachers' office. Another off record strategy appeared when the male student told the teacher that the water he brought was "yeh floridina (floridina water)" but actually it was dirty water. He was asked to take some water by his friend and he wanted to bring dirty water for her. Before the water was handed to his friend the teacher asked him what water that he brought. The reason he used this strategy because he wanted to tell a joke. He told a joke hoping that the teacher would not get mad because he took dirty water.

Impolite language was used in many topics of conversation they did outside the classroom. The reason of using impolite language was commonly 
because the students thought they were close enough to talk baldly to the teachers. From the interview, the researcher found that the students thought if they talk baldly to the teachers it would show that they were close to the teachers.

However, the specific reasons they used bald on record strategy when they talked to the teachers stated by some male students in the interview. One male student told that when he answered a new teacher's question about the students he would teach that day by saying, "Mati! ([they have] died!)", He just wanted to tell a joke. He added that he felt it was okay because he had already known the teacher. Other reason was stated by another male student of XI IIS class. He stated that he had a reason when he called the teacher because he was hit by XII grade students during the cleaning session. He called the teacher by saying, "Eh pak.." because he was in urgency. $\mathrm{He}$ was hit by the XII grade students using wet newspapers so that was why he reported it to the teacher directly. He was hoping the teacher would give the XII grade students a warning because they throw many rubbish in front of his class. Other male student was involved in the conversation that he told to the new teacher that the students in SMA Bhaktiyasa Singaraja were allowed to leave the school earlier if there was no any teacher taught them in the classroom. He stated the reason why he told the new teacher baldly about it because he thought the new teacher should know about that.

Other specific reasons were told by some female students. The first student told the researcher the reason she talked baldly to the teacher when she talked about the teacher's hobby to play games. She said that,

F1 :ne gurune main game gen gaene.. wifi gen.

(This teacher just spent his time to play game using Wi-Fi..."

She said it because she wanted to tell joke with the teacher. Another female student was also involved on the conversation in the cafeteria. She uttered that,
F3 : oooh pak..ne be
kejemakang jak yang... iiih...

(See.., I have taken your meal,,, iiih...)

She uttered that because she wanted the teacher know that she was kind to the teacher. Another case happened when a female student answered the teacher's question whether the students had done the cleaning or not. One female student answered directly, $\mathrm{F} 2$ :Be..

(Yes, we have)

She expressed the utterance used bald on record strategy because she used to answered question directly.

According to Brown \& Levinson theory (1987) bald on record strategy is done by the speaker has close relationship with the interlocutor. From the interview which was done with the students, the students stated that they talked baldly to the teacher because they thought they were close with the teachers. The reason that the students stated was similar to the reason bald on record used by speaker that the theory of politeness strategies proposed (Brown \& Levinson, 1987). However, the specific reasons that the students in XI IIS had when they talked to the teachers provided some addition possible reasons someone used bald on record strategy to talk to someone.

Besides, there are two cases a female student used positive politeness strategy. The first, when the student talked to a new teacher and the second was when the student congratulated a Balinese teacher for her birth day. The female student said that she talked to the new teacher in that way, because she did not know the teacher well and respected him because he was from the same village as her grandparent. For the second case, the female student said that it was because she wanted to respect the Balinese teacher on her birth day even though she was late to congratulate her.

According to Brown \& Levinson (1987), positive politeness is used to express the respect that the speaker has in order to fulfill the hearer's desire to be respected. It was also happened on this 
study, that the female student used positive politeness strategy because she recognized herself that she needed to respect the new teacher because he was new teacher in her school and she should respects her Balinese teacher because it was about her birth day.

The last strategy used by the students in XI IIS of SMA Bhaktiyasa Singaraja was off record strategy. The strategy was once used by a female student and once used by male student. The female student used the strategy because she do not want disappoint her teacher who asked her about other teachers who were in the office and used it to get help from her friend that might know the answer. Another case of off record strategy using was when a male student took dirty water to be used by his friend mop the floor. The teacher noticed it and asked him about the water. He did not directly said that it was dirty water but implicitly said it by telling to the teacher that it was 'yeh floridina' because he avoided the teacher got mad and told a joke to the teacher.

On the theory about politeness strategy which was proposed by Brown \& Levinson (1987), off record strategy is used to express something indirectly and implicitly. Both of the reasons stated by the students were because they wanted to tell the interlocutor implicitly about the real condition. So that was why both the indirect expressions that the students said to the teacher were categorized as off record strategy.

Both male and female students in XI IIS class mostly used same strategies to talk to their teachers whether it was in the classroom or outside the classroom. It was different from the previous study about politeness strategy used by male and female interviewer when they interviewed some people (Petrickova, 2012). On her study, the the male interviewer used positive politeness and the female interviewer tend to use negative politeness. However, on this study the researcher found that there was no any difference strategy that female students and male students chose. Both female and male students used bald on record strategy.
Female and male students mostly used bald on record strategy when they talked to the teachers outside the classroom. There was only a female student used positive politeness when she talked to new teacher and the Balinese teacher whom she wanted to congratulate because of the teacher's birth day. The female students changed the strategy into bald on record after several times met the new teacher. Male students still used bald on record to talk to the new teacher since the first time they met the new teacher. A female student used off record strategy when the teacher asked her about other teacher. A male student used off record strategy when he answered the teacher's question about the water he brought.

From those examples, it can be concluded that, gender did not really influence the used of politeness strategy. The use of politeness strategies found on this study, was influenced more by the context of the conversation.

\section{CONCLUSION AND SUGGESTIONS}

The answers of research problems have been shown in Findings and Discussion on the previous chapter. The conclusion of the study can be shown as follows:

The types of politeness strategies used by female and male students were bald on record strategy, positive politeness strategy, and off record strategy. the types of impolite language strategies used by them was only bald on record impolite language only. Impolite language was used by both female and male students when they talked to the teachers in the classroom and there are some bald on record politeness used. Impolite language was also used outside the classroom mostly. Positive politeness strategy was only used by a female student when she talked to a new teacher but changed into bald on record after she met the new teacher for several times. She used positive politeness strategy when she congratulated her Balinese teacher for the teacher's birth day, and telling jokes to the teacher. A male student used positive politeness when he told joke about the 
teacher's beard. Off record strategy was used by a female student and a male student. Both of them used this strategy to indirectly tell the interlocutor about something.

The reasons of the students used the strategies; bald on record impolite language, bald on record politeness, positive politeness, and off record strategy were depended on the context. They used bald on record impolite language and politeness strategy because they thought that they were close enough to the teachers. They used positive politeness to show their respect to the teachers in current context. They used off record strategy to implicitly told something to avoid the interlocutor to disappointed or mad..

Some suggestions can be derived from the result of analysis on result of observation, audio recording, and interview. The suggestion can be shown as follows:

\section{For Students}

From the interview, the students stated that they used impolite language because they used to use it in the classroom or outside the classroom. It showed that they were closed with the teachers but wrongly chose the strategies. They did not concern the context that they were talking to their teacher. It is suggested for the students to concern about the situation of the conversation. If the conversation was taken place in the classroom, they should used more polite language and avoid to use direct and bald expressions to talk to the teachers.

\section{For Other Researchers}

For other researchers who interested in conducting a study about politeness and impolite language strategies used in the school or used by female and male people, the researcher can develop this study. This study was still focused on the students' side only. The further study can be focused also on the teachers' strategies when they talked to the students.

\section{ACKNOWLEDGEMENTS}

Thanks to the Almighty God for his blessings, this thesis entitled "An Analysis of Politeness and Impolite language Strategies Used by Female and Male Students in XI IIS of SMA Bhaktiyasa Singaraja to Talk to Their Teachers Inside and Outside the Classroom" could be finished. The writer thanks to the people who give any contribution in completion of this thesis.

The thesis advisors, Prof. Dr. I Ketut Seken, M.A. and I Nyoman Pasek Hadisaputra, S.Pd., M.Pd., thank you for the suggestion, recommendation, and guidance during the completion of this thesis.

The academic supervisor, Dewa Ayu Agustini, S.Pd.,M.S., thank you for the advice during the study in English Education Department.

The head of SMA Bhaktiyasa Singaraja, Drs. I Wayan Gunarsa, M.Si, thank you for your permission, advice, and information during the data collection in your school.

The students of XI IIS SMA Bhaktiyasa Singaraja, thank you for being the subject of this study and the respondents of the interview.

The reviewer and supporter, Muhamad Nova, thank you for the support, advice, and revision during the completion of this thesis

The researcher hopes that this thesis will be useful for the development of linguistics and education. The researcher would also apologize if there are any mistakes on this thesis.

\section{REFERENCES}

Brown, P and S. C. Levinson (1987). Politeness: some universals in language usage. United Kingdom: Cambridge University Press. Retrieved from https://books.google. co.id/books?id=OG7W8yA2XjcC\&pr intsec $=$ frontcover\&hl=id\&source $=g b$ s ViewAPI\&redir esc $=\mathrm{y} \# \mathrm{v}=$ onepag e\&q\&f=false. May 17, 2015 
Bryman, A (2003) Triangulation (encyclopedia of social science research method).SAGE publication.Retrieved from http://www.sagepub.com/chambliss 4e/study/chapter/encyc pdfs/4.2 Tri angulation.pdf May 24, 2015.

Culpeper, J (2011) Impolite language: Using language to cause offense. New York: Cambridge University. SIL Electronic Book Reviews.retrieved from http://www.sil.org/system/files/reapd ata/74/71/92/747192985221437170 50558921180787414417/SILEBR 2 012 003.pdf September 42015

Laitinen, M (2010) "you're orange, you moron!": The use of impolite language strategies in the American TV series House D.M. Unpublished thesis. retrieved from http://www.google.co.id/url?sa=t\&cd $=7 \& \mathrm{rct}=\mathrm{i} \& \mathrm{q}=$ impolite

language\%20strategies\%20culpepe r\%20pdf\&ved=OCDcQFjAGahUKE wi1577C9e3HAhWMBY4KHS3CAp M\&url=https\%3A\%2Fbitstream\%2F handle $\% 2 \mathrm{~F} 123456789 \% 2 \mathrm{~F} 23458 \%$ 2Fmelina laitinen.pdf\&usg=AFQjCN F4vBYbxZKOxCIKLqznYLME7KF23 A September 112015

Miles, M. B. and A. M. Huberman (1994). An expanded sourcebook: qualitative data dnalysis. London: SAGE publications Ltd. International educational and professional publisher. Retrieved fromhttps://vivauniversity.files.wordp ress.com/2013/11/milesandhuberm an1994.pdf. May 17, 2015

Pariera, K (2006). The Use of Politeness Strategies in Email Discussions about Taboo Topics.Published Journal in Portland State University PSU McNair Scholars Online Journal Volume.2: Iss.1, article 29. Portland: Portland State University. Retrieved from http://pdxscholar.library.pdx.edu/cgi/ viewcontent.cgi?article $=1099 \&$ conte $\underline{\mathrm{xt}=\text { mcnair. June } 2,2015}$
Peng, L, F. Xie, L. Cai (2014). A case study of college teacher's politeness strategy in EFL classroom.ISSN 1799-2591 Theory and Practice in Language Studies, Vol. 4, No. 1, pp. 110-115, January 2014. China: Sichuan University of Science and Technology. Retrieved from http://ojs.academypublisher.com/ind ex.php/tpls/article/view/tpls0401110 $\underline{115 / 8421 \text { June } 2,2015}$

Petrickova, I. (2012). Politeness strategies in interview question. America: Masaryk University. Published Thesis in Masaryk University 2012 Retrieved from http://is.muni.cz/th/325815/ff b/Thes is.pdf.May 28,2014

Pinatih, N. P. A. Y. W (2014). An analysis of politeness strategy used by members of pasraman Adi Widya in Sumberkima village in classroom activity. Singaraja: Ganesha University of Education 